\title{
Absence of leukaemic fusion gene transcripts in preterm infants exposed to diagnostic $x$ rays
}

\author{
P F Ravetto, R Agarwal, M L Chiswick, S W D'Souza, O B Eden , G M Taylor
}

Arch Dis Child Fetal Neonatal Ed 2003;88:F237-F244

Background: Childhood leukaemias express novel, clonotypic fusion genes that may already be present at birth before the clinical manifestation of leukaemia. Exposure of the fetus to diagnostic $x$ rays is reported to increase the risk of childhood leukaemia, and may do so by generating leukaemic fusion genes. Advances in neonatal medicine in the past decade that have extended the limits of viability of preterm babies down to 23 weeks of gestation have resulted in the increased use of diagnostic $x$ rays to monitor neonatal progress.

Aim: To investigate whether exposure of very preterm infants to diagnostic $x$ rays in the neonatal period leads to the development of leukaemic fusion genes.

Methods: Peripheral blood samples were collected at birth from very preterm infants (23-30 weeks gestation) and following exposure to diagnostic $x$ rays at intervals of two weeks, until discharge. Cord blood samples from normal full term infants served as controls. Total RNA was extracted from the blood

See end of article for authors' affiliations

......................

Correspondence to: Dr G M Taylor, Immunogenetics Laboratory, St Mary's Hospital, Hathersage Road, Manchester MI3 $\mathrm{OJH}, \mathrm{UK}$;

gmtaylor@man.ac.uk

Accepted 27 August 2002 and the expression of the fusion genes TEL-AMLI, MLL-AF4, and BCR-ABL, characteristic of three subtypes of childhood leukaemia, was investigated in the preterm and full term infant samples using a nested reverse transcriptase polymerase chain reaction method. Serial pre- and post- $x$ ray samples from 42 preterm babies, pre- $x$ ray samples from an additional 46 preterm infants, and cord blood samples from 100 normal full term infants were screened for fusion gene transcripts.

Results: No leukaemic fusion gene transcripts were detected in preterm infants following exposure to diagnostic $x$ rays. A $B C R-A B L$ transcript was identified in a single preterm infant prior to $x$ ray exposure. TEL-AML 1 transcripts were detected in cord blood samples from two full term infants. MLL-AF4 transcripts were not detected in any of the pre- or full term infants tested.

Conclusions: Exposure of the preterm infants to $x$ rays in this small series and at the doses used for diagnostic purposes did not induce leukaemic fusion gene expression, but we cannot exclude the possibility that a small proportion of preterm infants may be unusually sensitive to $x$ rays.
T he increased risk of childhood leukaemia following exposure of the fetus to obstetric $x$ rays was first documented in 1956 by Stewart and colleagues, ${ }^{1}$ as part of the Oxford Survey of Childhood Cancer (OSCC). Among 269 cases of childhood leukaemia and an equal number of controls, they found that $15.6 \%$ of children with leukaemia compared with only $8.9 \%$ of control children had previously been exposed to $x$ rays in utero. Although Stewart and Kneale ${ }^{2}$ suggested that the risk was related to the radiation dose, these findings were initially greeted with scepticism. However, they were subsequently confirmed by others, ${ }^{3}$ by reanalysis of the OSCC data ${ }^{4}$ and in meta-analyses. ${ }^{5}$ The considerable reduction in the use of $x$ rays during pregnancy that these results have brought about $^{6}$ has made an important contribution to reducing the risk of childhood cancer and leukaemia arising from medical intervention. ${ }^{7}$

Developments in fetal and neonatal medicine in recent years have enabled an increasing proportion of babies born as early as $22-23$ weeks gestation to survive. ${ }^{8-10}$ However, the need to monitor neonatal progress, including respiratory disorders, means that very preterm infants often undergo a considerable number of $x$ ray examinations. ${ }^{1-15}$ While dose estimates suggest that the excess number of cancers owing to neonatal $x$ rays is extremely low, and far outweighed by the benefits in terms of neonatal fetal survival, ${ }^{1013} 1516$ increasing radiation exposure at a relatively early gestational stage is a matter of concern.

Uncertainties remain about exposing very preterm infants to radiation for the following reasons. (1) No long term follow up studies of cancer risk in relation to preterm birth have been published. (2) There appears to be no lower threshold dose for $x$ rays below which cancer does not constitute a risk. (3) Pre- term babies may differ from those born at term with respect to their $x$ ray sensitivity. (4) It has recently been shown that the novel fusion genes characteristic of certain childhood leukaemias can occur in normal infants.

Recent evidence ${ }^{17}$ suggests that chromosomal double strand breaks (DSBs), in some cases caused by ionising radiation, may lead to the acquired chromosomal translocations associated with the generation of the novel expressed hybrid or fusion genes that are typical of leukaemia. ${ }^{18-20}$ Studies of monozygotic twins who both developed leukaemia, in some cases at different ages, have revealed identical clonotypic fusion gene sequences in both twins that suggest that these arise before birth as a single event in one twin, and are transmitted to the other twin through the conjoined placental circulations. ${ }^{2122}$ Further evidence that fusion genes can arise prenatally comes from studies in which fusion genes have been backtracked to birth in children who later develop leukaemia. ${ }^{23}$

Leukaemic fusion genes provide potentially informative biomarkers of leukaemic cell populations, and the development of these genes as a consequence of the mis-repair of DSBs induced by diagnostic $x$ rays could provide an important measure of leukaemia risk associated with medical $x$ ray exposure. To investigate this specifically in preterm babies exposed to

Abbreviations: ALL, acute lymphoblastic leukaemia; $A M L$, acute myeloid leukaemia; DAP, dose area product; DSB, double strand break; ERR, excess relative risk; FFD, focus to film distance; NMU, neonatal medical unit; OSCC, Oxford Survey of Childhood Cancer; RT-PCR, reverse transcriptase polymerase chain reaction 
diagnostic $x$ rays, we have used a sensitive nested reverse transcriptase polymerase chain reaction (RT-PCR) to amplify fusion genes known to be associated with childhood leukaemias. Here, we describe our results using this assay to detect three types of fusion gene transcripts: TEL-AML1, generated by the fusion of the TEL(ETV6) gene on chromosome 12 with the AML1 (CBFA2) gene on chromosome 21 , and present in $\sim 20-25 \%$ of childhood precursor B cell acute lymphoblastic leukaemia (ALL) ${ }^{24}$; $M L L-A F 4$, generated by the fusion of the MLL gene on chromosome 11 with the AF4 gene on chromosome 4, and found in at least $70 \%$ of infant ALL and acute myeloid leukaemia (AML) ${ }^{25}$; and $B C R-A B L$, generated by the fusion of the $B C R$ gene on chromosome 9 with the $A B L$ gene on chromosome 22 and found in under $5 \%$ of childhood ALLs. ${ }^{26}$

\section{METHODS \\ Study population}

The study was carried out on preterm babies born at 23-30 weeks gestation who were admitted to the Neonatal Medical Unit (NMU) at St Mary's Hospital, Manchester between 1998 and 2000. The study had ethical approval from the Central Manchester \& Manchester Children's University Hospitals NHS Trust local research ethics committee. Blood samples $(\sim 0.5 \mathrm{ml})$ from preterm infants and clinical data were obtained with informed maternal consent. A total of 88 preterm infants born between 23 and 30 weeks of gestation were included in the study. Blood samples were collected in sterile $5 \mathrm{ml}$ bottles containing $1 \mathrm{ml}$ of cell culture medium (RPMI 1640 with Glutamax $\mathrm{l}$ and $25 \mathrm{mM}$ HEPES, Life Technologies Ltd, Paisley, UK) and $30 \mu \mathrm{lEDTA}$, as soon after birth as possible, and prior to $x$ ray exposure, and then subsequently at two weekly intervals until discharge. Cord blood samples obtained from an anonymised series of normal full term infants served as non $x$ rayed controls.

Clinical details of the preterm babies and their mothers were obtained from obstetric and paediatric case notes, and included data on obstetric conditions, birth details, and resuscitation. Neonatal information included the need for ventilator support, oxygen dependence, and details of drugs administered and blood transfusions.

\section{$x$ Ray dosimetry}

All of the exposures were undertaken using a Hitachi Sirius 125B mobile $x$ ray unit located on the NMU. The date, time, type of examination, exposure factors, and the area of the baby exposed to $x$ rays to the nearest $\mathrm{mm}^{2}$ were measured for each radiograph. The $x$ ray output of the machine was measured using a calibrated dose meter over a range of clinical exposure factors. The dose area product (DAP) was calculated from the appropriate output, corrected for focus to film distance (FFD), $x$ ray transmission of incubator lid and exposed area of each film. Since radiation risk is normally quantified by "effective dose", correction factors to convert DAP to effective dose have been published by the National Radiological Protection Board (NRPB) ${ }^{27}$ However, appropriate risk data are not available for calculating this dose in preterm babies $\leqslant 1500 \mathrm{~g}$. As an alternative, the "energy imparted" to the infant was used as a measure of radiation risk. This was calculated as follows: energy imparted $(\mathrm{mJ})=$ dose in air at FFD $\times$ area of field $\left(\mathrm{cm}^{2}\right) \times$ conversion factor. ${ }^{14}$ Mean absorbed doses received by individual infants were subsequently calculated in relation to body weight.

\section{Cell lines}

Reference cell lines derived from leukaemias expressing the relevant fusion genes were used as positive controls, and were obtained from the German Collection of Microorganisms and Cell Cultures, Braunschweig, Germany (http:// www.dsmz.de/). These were as follows: $\mathrm{REH}^{28}$ expressing TELAML1; MV4; $11^{29}$ expressing MLL-AF4; and BV173 ${ }^{30}$ expressing $B C R-A B L$. An Epstein-Barr virus transformed normal lymphoblastoid cell line (SV18), prepared from a normal donor, and not expressing the above fusion genes, was used as a negative control. All cell lines were cultured in RPMI-1640 containing $10 \%$ fetal calf serum.

\section{RNA extraction}

Total RNA was extracted from whole blood samples and from the fusion gene positive and negative reference cell lines using RNeasy Standard and Blood Mini Kits (Qiagen Ltd, Crawley, UK). The RNA was eluted in $40 \mu \mathrm{l}$ of RNase free water; $1 \mu \mathrm{l}$ of this was diluted $1 / 50$ and used to measure the Optical Density ${ }_{260 / 20}$ in order to obtain the yield, concentration, and purity of the RNA. To avoid cross contamination, all RNA extractions were carried out in a separate laboratory using dedicated pipettes and aerosol resistant tips.

\section{Amplification of fusion gene transcripts by RT-PCR}

Leukaemic fusion gene transcripts were amplified using a nested reverse transcriptase (RT) polymerase chain reaction (PCR) method. A $1 \mu \mathrm{g}$ aliquot of total RNA was amplified using Ready-To-Go RT-PCR beads (Amersham Pharmacia Biotech, Amersham. UK). Reactions were carried out in 0.2 $\mathrm{ml}$ tubes, each containing a lyophilised bead comprising the reagents required for performing a single tube RT-PCR reaction. To each tube $1 \mu \mathrm{g}$ total RNA, $1.5 \mu \mathrm{l}$ oligo $(\mathrm{dT})_{12-18}$ primer $(0.5 \mu \mathrm{g} / \mu \mathrm{l})$, and $6 \mu \mathrm{l}$ of first round PCR primers $(5 \mu \mathrm{M}$ each) ${ }^{21} 243233$ (see table 1) were added, and the volume brought to $60 \mu \mathrm{l}$ with RNase free water. Reaction mixtures were vortexed to fully dissolve the beads, centrifuged, and incubated at $42^{\circ} \mathrm{C}$ for one hour to carry out cDNA synthesis. First round PCR was then performed in the same tubes on a PCR Express thermocycler (Hybaid, Middlesex, UK) using the following conditions: 3 minutes at $94^{\circ} \mathrm{C}, 32$ cycles of $94^{\circ} \mathrm{C}$ for 30 seconds, $66^{\circ} \mathrm{C}$ for 30 seconds $(T E L-A M L 1), 64^{\circ} \mathrm{C}(M L L$ $A F 4)$ or $58^{\circ} \mathrm{C}(B C R-A B L), 72^{\circ} \mathrm{C}$ for 30 seconds, and finally $72^{\circ} \mathrm{C}$ for 3 minutes. A $2 \mu \mathrm{l}$ aliquot of the RT-PCR products were then subjected to second round amplification using internal primers $^{21} 243233$ (table 1) as follows: $2 \mu \mathrm{l} 10 \times$ PCR buffer (200 mM Tris $\mathrm{HCl}, 500 \mathrm{mM} \mathrm{KCl}, \mathrm{pH} 9.0$ ), $2 \mu \mathrm{l}$ primer mix ( $5 \mu \mathrm{M}$ each), $3 \mu \mathrm{l}$ dNTPs ( $2 \mathrm{mM}$ each), $1.5 \mu \mathrm{lgCl}_{2}(25 \mathrm{mM}$ ), $1 \mu \mathrm{l} \mathrm{Wl}(1 \%), 0.1 \mu \mathrm{l}$ Taq DNA polymerase $(5 \mathrm{U} / \mu \mathrm{l})$ (Gibco, Life Technologies Ltd, UK), $8.4 \mu \mathrm{l} \mathrm{H}_{2} \mathrm{O}$, and $2 \mu \mathrm{l}$ first round PCR product. Second round cycling conditions were: $94^{\circ} \mathrm{C}$ for 3 minutes, 38 cycles of $94^{\circ} \mathrm{C}$ for 15 seconds, $55^{\circ} \mathrm{C}$ for 15 seconds, $72^{\circ} \mathrm{C}$ for 15 seconds, and a final step at $72^{\circ} \mathrm{C}$ for 3 minutes. Fusion of the $B C R$ and $A B L$ genes may give rise to several hybrid transcripts owing to alternative splicing. ${ }^{34}$ In order to detect commonly expressed $B C R-A B L$ transcripts two pairs of first and second round primers were used in multiplex reactions. ${ }^{33}$ As a control for RNA integrity separate PCR amplifications were carried out on each sample to detect $\beta$ actin expression. All second round PCRs were carried out in five replicates. To prevent cross contamination separate areas were used to set up PCRs, to carry out amplifications, and to analyse the PCR products. Dedicated pipettes with aerosol resistant tips were used to prepare PCR mixtures. Distilled water was used as a negative control for PCR.

\section{Detection of fusion gene transcripts}

To detect PCR amplification, $5 \mu$ l of each PCR product was electrophoresed in a $2 \%$ agarose gel, stained with ethidium bromide, and photographed under ultraviolet light (Biorad Gel Doc 2000, BioRad UK, Hemel Hempstead). The remaining PCR product was dot blotted onto positively charged nylon membranes (Hybond-N+, Pharmacia, 
Table 1 First and second round fusion gene primers and breakpoint specific SSO probes

\begin{tabular}{|c|c|c|c|c|}
\hline & $5^{\prime}-3^{\prime}$ sequence & Specificity & Location & Ref \\
\hline \multicolumn{5}{|l|}{ Primer } \\
\hline TELS84 1 & ATC ATG CAC CCT CTG ATC CT & TEL-AMLI & $5^{\prime}$ external & 21 \\
\hline AMLAS765 & TGG GCA GGG TCT TGT TGC AG & TEL-AMLI & 3' external & 21 \\
\hline B12 & CGT GGA TTT CAA ACA GTC CA & TEL-AMLI & $5^{\prime}$ internal & 24 \\
\hline $\mathrm{AM} 3$ & CTC GCT CAT CTT GCC TGG & TEL-AMLI & $3^{\prime}$ internal & 24 \\
\hline MLLAF4A & AGA GCA GAG CAA ACA GAA & MLL-AF4 & $5^{\prime}$ external & 32 \\
\hline MLLAF4B & GCT GAG AAT TTG AGT GAG & MLL-AF4 & 3' external & 32 \\
\hline MLLAF4C & AAG TGG CTC CCC CGC CCA AGT AT & MLL-AF4 & $5^{\prime}$ internal & 32 \\
\hline MLLAF4D & TTG GGT TAC AGA ACT GAC ATG & MLL-AF4 & $3^{\prime}$ internal & 32 \\
\hline BCRA & CGG GAG CAG CAG AAG AAG TC & $B C R-A B L b 2 a 2 / b 3 a 2$ & 5 ' external & 33 \\
\hline BCRC & TTG TCG TGT CCG AGG CCA CC & $B C R-A B L$ ela2 & $5^{\prime}$ external & 33 \\
\hline ABLA & TGT GAT TAT AGC CTA AGA CCC GGA G & $B C R-A B L b 2 a 2 / b 3 a 2 / e 1 a 2$ & 3' external & 33 \\
\hline$B C R B$ & GTG AAA CTC CAG ACT GTC CAC AGC A & $B C R-A B L b 2 a 2 / b 3 a 2$ & $5^{\prime}$ internal & 33 \\
\hline $\mathrm{BCRD}$ & CAA GAC CGG GCA GAT CTG GCC C & $B C R-A B L$ e la2 & $5^{\prime}$ internal & 33 \\
\hline$A B L B$ & TCC ACT GGC CAC AAA ATC ATA CAG T & $B C R-A B L b 2 a 2 / b 3 a 2 / e 1 a 2$ & $3^{\prime}$ internal & 33 \\
\hline$\beta-A C T I N 5^{\prime}$ & TGA AGT CTG ACG TGG ACA TC & $\beta$-ACTIN 5' & $5^{\prime}$ & \\
\hline B-ACTIN 3, & ACT CGT CAT ACT CCT GCT TG & $\beta$-ACTIN 3' & $3^{\prime}$ & \\
\hline \multicolumn{5}{|l|}{ Probe } \\
\hline TEL-AML1 P1 & AGA ATA GCA GAA TGC ATA CTT & Probe 267 bp transcript TEL-AML 1 & & 31 \\
\hline TEL-AML 1 P2 & GAA TAG CAG ATG CCA GCA C & Probe 228 bp transcript TEL AML 1 & & 31 \\
\hline AF4 P & TAG GGA AAG GAA ACT TGG ATG & Probe MLL-AF4 & & 32 \\
\hline$b 2 a 2 P$ & GCT GAA GGG CTT CTT CCT TAT TGA TG & Probe $b 2 a 2$ transcript $B C R-A B L$ & & 33 \\
\hline b3a $2 P$ & GCT GAA GGG CTT TTG AAC TCT GCT TA & Probe b3a2 transcript BCR-ABL & & 33 \\
\hline ela2 P & GCT GAA GGG CTT CTG CGT CTC CAT & Probe e la2 transcript $B C R-A B L$ & & 33 \\
\hline
\end{tabular}

Amersham, UK) using a vacuum manifold. The PCR products were denatured in situ with $0.5 \mathrm{M} \mathrm{NaOH}, 1.5 \mathrm{M} \mathrm{NaCl}$ followed by $1.5 \mathrm{M} \mathrm{NaCl}, 0.5 \mathrm{MTris} \mathrm{HCl}(\mathrm{pH} 7.4)$, and the membranes baked at $80^{\circ} \mathrm{C}$ for two hours to fix the DNA. The fixed PCR products were then hybridised with $10 \mathrm{pmol}$ of a translocation junction specific oligonucleotide probes labelled with $10 \mu \mathrm{Ci} \gamma^{32} \mathrm{P}$-adenosine triphosphate (ATP) by T4 polynucleotide kinase (Promega, Southampton, UK)..$^{31-33}$ Hybridisation was carried out at $58^{\circ} \mathrm{C}$ overnight, and the membranes washed briefly at room temperature in $2 \times \mathrm{SSC} /$ $0.1 \%$ SDS followed by a second wash with tetramethyl ammonium chloride (TMAC) solution (3.0 M TMAC, $50 \mathrm{mM}$ Tris-HCl pH 8.0, 2 mM EDTA pH 8.0, 0.1\% SDS) at $58^{\circ} \mathrm{C}$ for 15 minutes. The membranes were sealed between plastic film, and autoradiography, to detect probe hybridisation, was carried out in real time on an InstantImager (Canberra Packard, Berkshire, UK).

\section{Sensitivity of fusion gene transcript detection}

Experiments were carried out to determine the sensitivity of the nested RT-PCR fusion gene assay. RNA ( $1 \mu \mathrm{g})$ samples from the leukaemic reference cell lines carrying TEL-AML1, $M L L-A F 4$, or $B C R-A B L$ were serially diluted $\left(10^{-1}-10^{-6}\right)$ with RNA from the fusion gene transcript negative control cell line SV18, and subjected to nested RT-PCR, then probed as described above.

\section{Direct sequencing of fusion gene products}

Positive PCRs were cycle sequenced using ABI BigDye terminator cycle sequencing reactions (version 2). Briefly, $8 \mu \mathrm{l}$ of Terminator Ready Reaction mix (Applied Biosystems, Warrington, UK) was added to $3.2 \mathrm{pmol}$ of each primer, $5 \mathrm{ng}$ of purified PCR product, and deionised water in a volume of $20 \mu \mathrm{l}$, and the reactions amplified on a PCR Express thermal cycler (Hybaid, Middlesex, UK) as follows: 25 cycles of $96^{\circ} \mathrm{C}$ for 10 seconds, $50^{\circ} \mathrm{C}$ for 5 seconds, and $60^{\circ} \mathrm{C}$ for 4 minutes. Extension products were purified by precipitation with $95 \%$ ethanol and $3 \mathrm{M}$ sodium acetate ( $\mathrm{pH} 4.6$ ), pelleted, and washed with $70 \%$ ethanol. Sample pellets were resuspended in Template Suppression Reagent (Applied Biosystems, Warrington, UK) and electrophoresed on an ABI 310 Prism Genetic Analyser (Applied Biosystems).

\section{RESULTS}

\section{Study group}

We obtained blood samples from 88 very preterm infants born between 23 and 30 weeks gestational age. The clinical characteristics of these infants and their mothers were similar to a larger series of 230 preterm infants (which included the sampled group), born between 23 and 30 weeks during the same period (table 2). This suggests that the sampled group was truly representative of the preterm infants on the NMU over the period of the study. We also obtained serial blood samples from 42 of the 88 preterm infants after they had been exposed to diagnostic $x$ rays. Post $x$ ray samples could not be obtained from about half of these infants $(n=46)$ because they were either transferred back to their referring hospital or died within the first two weeks postnatally from prematurity or other causes.

\section{$x$ Ray dosimetry}

Table 3 shows details of $x$ rays in relation to postnatal age in the group of 42 preterm infants serially blood sampled after $x$ ray exposure. In the first two weeks postpartum these infants had 1-19 $x$ ray episodes, the mean number/infant being 6.9. The number of $x$ rays received by the total sampled series of 42 preterm infants while on the NMU was 483, the maximum number of $x$ ray episodes for an individual baby being 43 over an eight week period. Mean absorbed doses received by infants in the first two weeks ranged from 0.002 to $0.13 \mathrm{mGy}$, the maximum mean absorbed dose received by an individual infant being $0.32 \mathrm{mGy}$ over an eight week period.

\section{Detection of fusion gene expression}

Since we were not certain whether cells carrying leukaemic fusion gene transcripts would be present in preterm infants, either before or after $x$ ray exposure, we used a sensitive nested RT-PCR assay to detect small numbers of fusion gene expressing cells. Tests on RNA from the reference leukaemia cell lines (REH, MV4;11, and BV173) diluted with normal RNA (SV18) showed that our method amplified leukaemic fusion genes with sensitivity thresholds of $10^{-6}$ for TEL-AML1, $10^{-5}$ for $M L L$ $A F 4$, and $10^{-4}$ for $B C R-A B L$ (fig 1 ). 


\begin{tabular}{|c|c|c|c|c|}
\hline \multirow{2}{*}{$\begin{array}{l}\text { Infant and maternal } \\
\text { characteristics }\end{array}$} & \multicolumn{2}{|c|}{$\begin{array}{l}\text { Fusion gene } \\
\text { tested } n=88\end{array}$} & \multicolumn{2}{|c|}{$\begin{array}{l}\text { Total infant serie } \\
\mathrm{n}=230\end{array}$} \\
\hline & $\mathrm{n}$ & $\%$ & $\mathrm{n}$ & $\%$ \\
\hline \multicolumn{5}{|l|}{ Infants } \\
\hline Male & 45 & 51 & 119 & 52 \\
\hline Female & 43 & 49 & 111 & 48 \\
\hline \multicolumn{5}{|l|}{ Birth weight (g) } \\
\hline$<750$ & 25 & 28 & 66 & 29 \\
\hline $751-1250$ & 46 & 52 & 114 & 49.5 \\
\hline$>1251$ & 17 & 19 & 50 & 21.5 \\
\hline \multicolumn{5}{|l|}{ Gestational age (wk) } \\
\hline$\leqslant 25$ & 21 & 24 & 55 & 24 \\
\hline $26-28$ & 36 & 40 & 81 & 35 \\
\hline$\geqslant 29$ & 31 & 35 & 94 & 41 \\
\hline \multicolumn{5}{|l|}{ Ethnicity } \\
\hline Caucasian & 73 & 83 & 182 & 79 \\
\hline Asian & 7 & 8 & 31 & 13.5 \\
\hline Afro-Caribbean & 2 & 2 & 7 & 3 \\
\hline Oriental & 3 & 3.5 & 3 & 1.5 \\
\hline \multirow{2}{*}{\multicolumn{5}{|c|}{ Mothers }} \\
\hline & & & & \\
\hline \multicolumn{5}{|l|}{ Parity } \\
\hline Primiparous & 30 & 34 & 59 & 25.5 \\
\hline Multiparous & 58 & 66 & 171 & 74.5 \\
\hline Singleton birth & 62 & 70.5 & 170 & 74 \\
\hline Multiple births & 26 & 29.5 & 60 & 26 \\
\hline Pregnancy induced hypertension & 22 & 25 & 56 & 24 \\
\hline PROM & 25 & 28 & 63 & 27 \\
\hline \multicolumn{5}{|l|}{ Delivery } \\
\hline Vaginal & 48 & 54 & 118 & 51 \\
\hline LSCS & 40 & 46 & 112 & 49 \\
\hline \multicolumn{5}{|l|}{$\mathrm{O}_{2}$ dependence } \\
\hline 28 days & $31 / 40$ & 77.5 & $75 / 120$ & 62.5 \\
\hline 36 weeks & $13 / 23$ & 56.5 & $37 / 86$ & 43 \\
\hline PDA & 28 & 32 & 50 & 22 \\
\hline NEC & 11 & 12.5 & 27 & 12 \\
\hline ROP & 5 & 6 & 8 & 3.5 \\
\hline Sepsis & 32 & 36 & 94 & 41 \\
\hline Mortality & 18 & 20.5 & 52 & 22.5 \\
\hline
\end{tabular}

PROM, premature rupture of fetal membranes; LSCS, lower segment caesarean section; PDA, patent ductus arteriosus; NEC, necrotising enterocolitis; ROP, retinopathy of prematurity.

\section{Analysis of preterm and control blood samples for fusion genes}

Blood samples from the total series of 88 preterm infants were tested for the expression of the three leukaemic fusion genes (TEL-AML1, MLL-AF4, and BCR-ABL) by nested RT-PCR. These samples included 46 preterm infants obtained at birth, and serial samples from 42 preterm infants obtained both before and at two weekly intervals after $x$ ray exposure. The serial samples from the 42 infants totalled 136 (42 pre- $x$ ray, 94 post- $x$ ray), the number of post- $x$ ray samples ranging from one to four per infant (table 4).

We did not detect any of the three types of leukaemic fusion gene transcripts in the preterm infant samples following $x$ ray

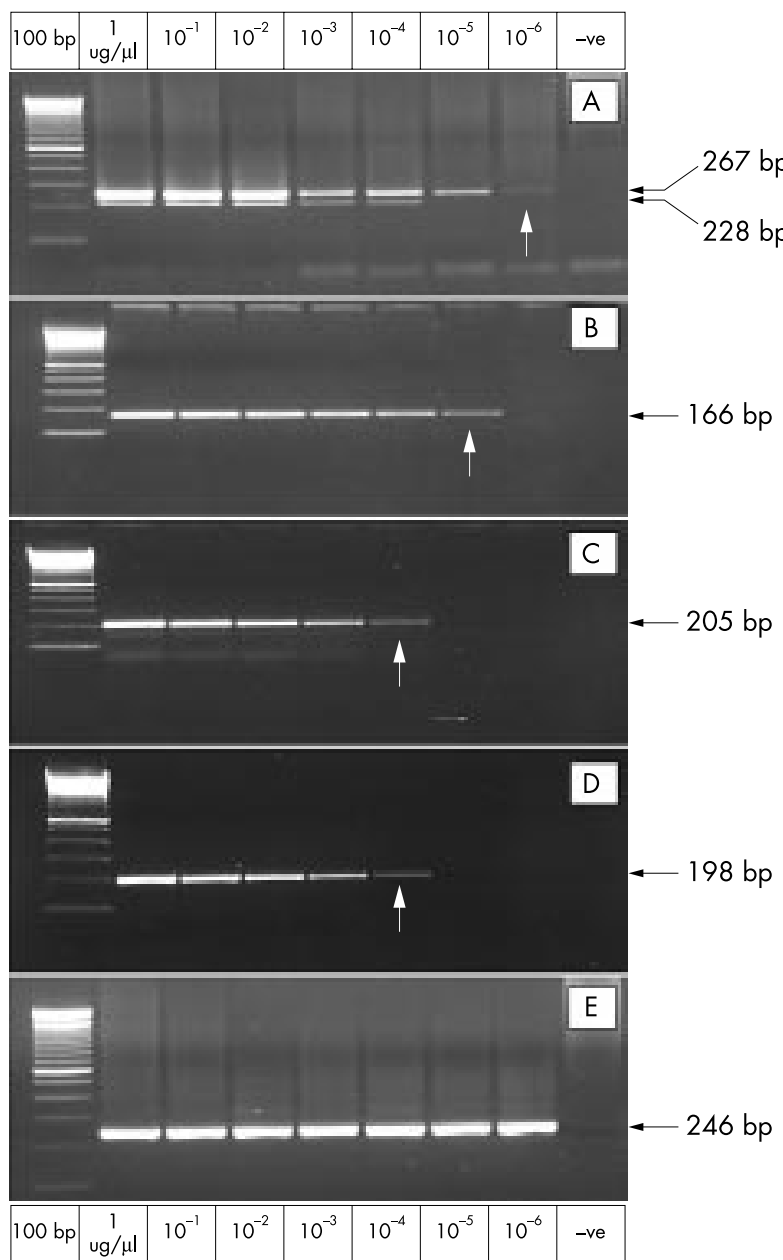

Figure 1 RT-PCR sensitivity experiments. (A) TEL-AML1 (REH). (B) MLL-AF4 (MV4;1 1). (C) BCR-ABL minor breakpoint junction (BV 173). (D) BCR-ABL major breakpoint junction (BV173). (E) $\beta$ actin positive control (REH). Arrows indicate sensitivity threshold.

exposure. However, we detected a $B C R-A B L$ transcript in one preterm infant (fig 2) prior to $x$ ray exposure. This infant was one of a pair of identical twins (twin 1) born at 27 weeks gestation. Discordant amniotic fluid volumes indicated that the twins exhibited feto-fetal transfusion syndrome and amniotic fluid reduction was carried out two weeks prior to delivery. At birth twin 1 (the donor) had oligohydramnios, and weighed $971 \mathrm{~g}$. A haemoglobin of $97 \mathrm{~g} / \mathrm{l}$ necessitated five blood transfusions, the first of which preceded blood sampling for fusion gene transcript analysis by 24 hours. Twin 1 was reviewed after about four months and was making excellent progress. Twin 2 (the recipient) had a birth weight of $1176 \mathrm{~g}$ and a

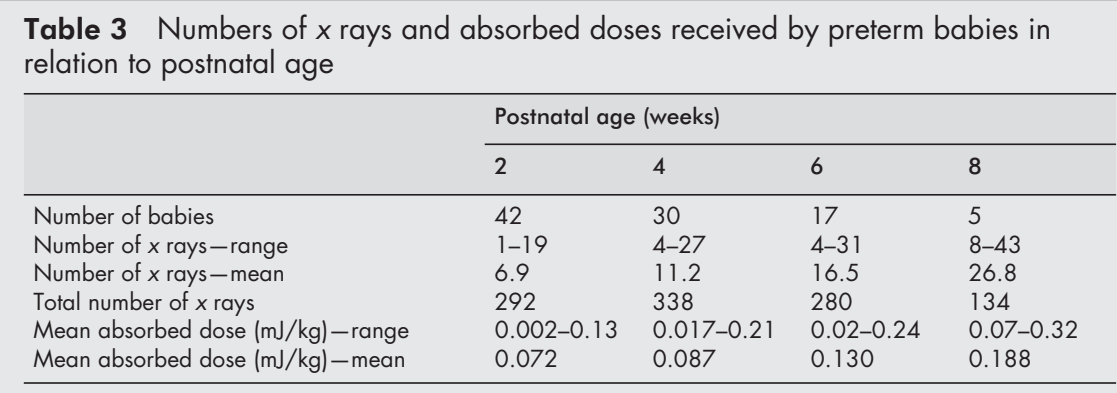



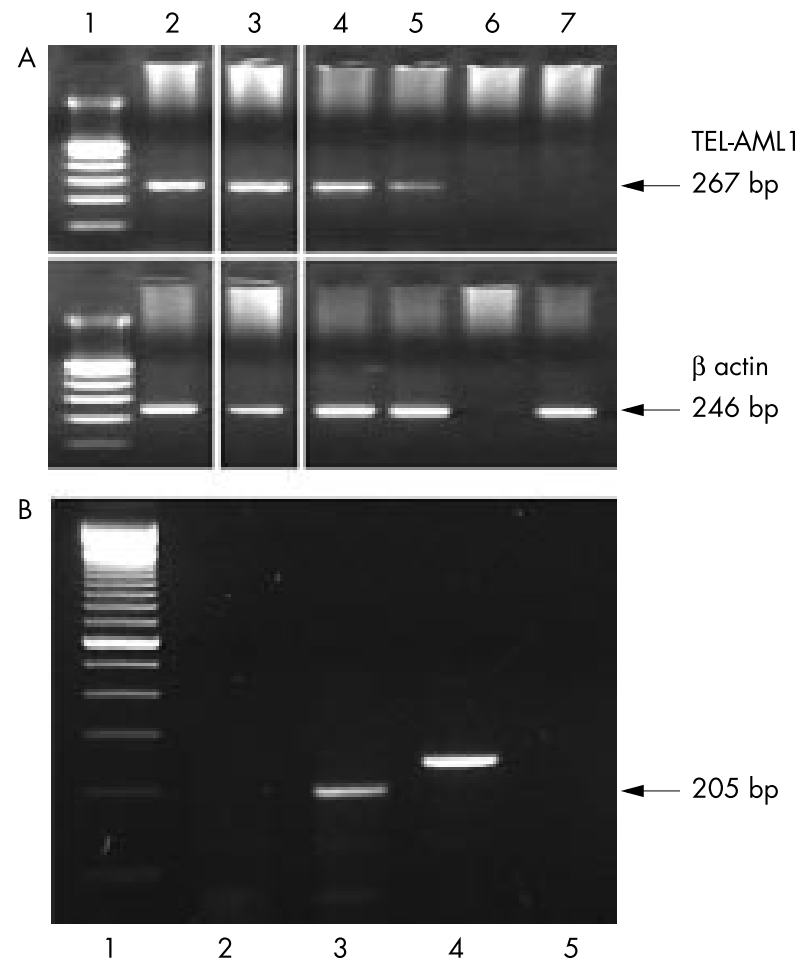

Figure 2 (A) Second round TEL-AML1 transcript showing positive full term infant cord blood samples. Lane 1, 100 bp ladder; 2, positive cord blood (a); 3 , positive cord blood (b); $4,10^{-4}$ REH (TEL-AML 1+) cells diluted in SV18 (normal lymphoid) cells; 5, as 4, but REH diluted $10^{-5}$ with SV18; 6, water (negative) control; 7 , normal lymphoid cell line SV18. (B) Second round BCR-ABL transcript from single preterm infant sample (for details, see text). Lane 1, 100 bp ladder; 2, b2a2/b3a2 (p210) transcript; 3, Ela2 (p190)

transcript; $4, \beta$ actin positive control; 5 , water (negative) control.

haemoglobin of $191 \mathrm{~g} / \mathrm{l}$. Unfortunately no blood sample for fusion gene analysis was available from twin 2.

In the cord blood samples from 100 normal full term non $x$ rayed control infants, we detected TEL-AML1 fusion gene expression in two infants (fig 2).

\section{Sequencing of fusion gene transcripts}

RNA preparations from the three infants (one preterm, two full term) expressing fusion gene transcripts were reamplified in RT-PCR and cycle sequenced to determine the nucleotide sequences of the breakpoint junctions, in comparison with the same sequences in the Genbank database. The BCR-ABL transcipt in the preterm infant (twin 1 ) had the same sequence as the $B C R-A B L$ minor breakpoint sequence coding the $190 \mathrm{kD}$ (p190) minor breakpoint peptide of the BCR/ABL protein (GenBank accession number AF113911). Both of the TEL$A M L 1$ transcipts from the full term infants included the $39 \mathrm{bp}$ exon 2 of the $A M L 1$ gene commonly expressed by this fusion gene (GenBank accession number S78496).

\section{DISCUSSION}

It is known that exposure of the fetus to $x$ rays in utero increases the risk of childhood leukaemia by about $40 \%,{ }^{1-7}$ and it has been suggested that there is no lower threshold dose below which there is no risk from prenatal radiation exposure. ${ }^{7}$ Since very preterm babies born between 24 and 30 weeks are the equivalent of second/third trimester fetuses, exposure to $x$ rays in the immediate postnatal period might be expected to pose a similar risk to exposure in utero, though the radiation doses used for preterm babies are lower than those that were associated with an increase risk of leukaemia following in utero exposure. Fletcher and colleagues ${ }^{11}$ estimated that at an average radiation dose to the chest or abdomen, neonates received about $0.07 \mathrm{mGy}$, sufficient to cause only about two extra cases of childhood cancer each year in the UK. Sutton and colleagues ${ }^{15}$ quantified the exposure of 55 very low birthweight neonates (mean gestational age 28.8 weeks) who received a total of 498 radiographs and three radiological procedures (median five per infant), and found a mean surface entrance dose of $33.1 \mu \mathrm{Gy}$ and a mean absorbed dose of $0.04 \mathrm{mGy}$. This contrasts with the 42 very preterm infants babies serially blood sampled after $x$ ray exposure in our study who were exposed to $1-19 x$ ray procedures in the first two weeks postpartum, the mean number per infant being 6.9 with a maximum absorbed dose of 0.32 mGy over an eight week period, compared with 54 mGy over 30 weeks reported by Sutton and colleagues. ${ }^{15}$ Unlike radiation doses delivered for typical $x$ ray examinations in adults where there has been progress towards dose standardisation, ${ }^{35}$ no such national standards exist for preterm $x$ rays. This may explain why the average effective dose imparted to infants under 2 years old undergoing head computed tomography scans reported in one study was six times higher than that for adults. $^{36}$

In vitro studies have shown that exposure of cell lines to radiation, albeit at high doses, can lead to the generation of leukaemic fusion genes. ${ }^{37}{ }^{38}$ Although the risk of developing leukaemia from the $x$ ray doses used in preterm babies is extremely low, ${ }^{1013}$ the absence of a lower dose threshold does not rule out a biological effect. Stochastic events resulting from radiation induced DNA damage may be misrepaired, leading to the chromosome translocations and the generation of leukaemic fusion genes that characterise childhood leukaemias. Although the physical effects of radiation exposure and their biological consequences, in terms of DNA breakage and consequent instability have been studied in detail $^{39}$ the long term effects of single $(\alpha)$ particles on lymphocytes have only been studied relatively recently. ${ }^{40}$ Even though it is not yet possible to predict the effects of a single $x$ ray track delivered to the haemopoietic cells of a preterm baby, recent evidence suggests that it is the proximity of the partner genes involved in translocations that may be an important factor in their development. ${ }^{41}$ In the case of the $\mathrm{ABL}$ and BCR genes, irradiation of lymphocytes alters chromatin structure, leading to shortening of the distances between these genes, thereby increasing the probability of translocation. ${ }^{42}$

Table 4 Number of blood samples and tests for leukaemic fusion genes

\begin{tabular}{|c|c|c|c|c|c|c|}
\hline \multirow[b]{2}{*}{ Group } & \multicolumn{2}{|l|}{ Infants } & \multicolumn{4}{|c|}{ Number of tests } \\
\hline & Number & Samples & TEL-AML1 & MLL-AF4 & BCR-ABL & Total \\
\hline Preterm & 88 & 182 & 910 & 910 & 910 & 2730 \\
\hline pre-x ray & 46 & 46 & 230 & 230 & 230 & 690 \\
\hline pre- and post-x ray & 42 & 136 & 680 & 680 & 680 & 2040 \\
\hline Full term & 100 & 100 & 500 & 500 & 500 & 1500 \\
\hline
\end{tabular}


Evidence that certain leukaemic fusion genes can occur prenatally ${ }^{23}{ }^{43}$ means that they are a potentially important biomarker of incipient leukaemia. ${ }^{22}$ However, the detection of fusion genes such as $B C R-A B L$ in normal adults ${ }^{44} 45$ and TEL$A M L 1$ in children ${ }^{46-48}$ suggests that other mutations are required for the development of overt leukaemia. We assumed that exposure to $x$ rays might result in the generation of fusion genes in preterm infants, but it is possible that $x$ rays might increase their frequency and the probability of causing additional mutations, in a dose dependent manner. We used a nested RT-PCR technique that is capable in our hands of detecting $0.001-0.0001 \%$ fusion gene positive cells among a large excess of cells not expressing fusion genes. This level of sensitivity was required since we had no prior indication of the number of fusion gene positive cells that were present. We screened for TEL-AML1, $M L L-A F 4$, and $B C R-A B L$ transcripts as these are among the commonest fusion genes in childhood leukaemia. Since most of the infants in our study were at the limits of viability, we were only able to obtain about $0.5 \mathrm{ml}$ of blood from each infant, and the number available for serial study was limited by early mortality and other clinical considerations. Although we detected no fusion gene transcripts in any of the post- $x$ ray samples, this does not rule out the possibility that $x$ rays may have caused other biological effects. Moreover, we tested samples obtained over a period of 2-8 weeks after $x$ rays, which may have been insufficient time to detect the long term effects of genomic instability on the development of fusion genes. ${ }^{49}$ We detected a fusion gene transcript $(B C R-A B L)$ in only one preterm baby, and we strongly suspect that this originated from transfused blood. Bearing in mind the limitations of our sampling method, and that we only tested peripheral blood, our results suggest that any fusion genes that do arise during gestation may occur at a later stage. This contrasts with the findings of Uckun and colleagues $^{32}$ who detected MLL-AF4 transcripts in 4/16 fetal bone marrow and 5/13 fetal liver samples from 15-22 week abortuses. Our failure to detect MLL-AF4 transcripts in preterm and normal full term infants agrees with the findings of Trka and colleagues ${ }^{48}{ }^{50}$ and Kim-Rouille and colleagues, ${ }^{51}$ and contrast with evidence of a high frequency of partial tandem duplications in the $M L L$ gene in normal donors. $^{52}$

Although our results are reassuring in suggesting that $x$ ray exposure of preterm babies may not lead to the development of leukaemic fusion genes, this conclusion needs to be treated with caution. Leukaemic fusion genes clearly do arise in utero in a small percentage of normal infants as shown in this and other studies. The argument that fusion genes are not induced by fetal exposure to radiation seems untenable if dose extrapolation from epidemiological studies suggesting "that there is no threshold dose below which no effect is produced" ${ }^{\prime 7}$ is correct. The explanation may therefore be that leukaemic fusion genes are not generated in sufficient numbers or in the appropriate target cells by the $x$ ray doses currently used in preterm babies. The annual dose of background radiation results in the delivery of about $1 \mathrm{mGy}$ of $\gamma$ rays to an $8 \mu \mathrm{m}$ nucleus. ${ }^{53}$ In comparison, the maximum absorbed dose that we observed was $0.32 \mathrm{mGy}$ over an eight week period. If continued for a year, this would roughly double the annual dose received by preterm babies. If we take the radiation risk coefficient for childhood leukaemia as being $2.5 \% / \mathrm{Gy},{ }^{7}$ this would lead to an individual probability of developing radiogenic leukaemia from preterm $x$ ray examination of about 1 in a million. So while the molecular effects of $x$ ray exposure may not be negligible, radiation risk estimates suggest that the risk to preterm babies is minute. Looked at another way, although the risk of childhood leukaemia is approximately 1 in 1760 under 15 years of age, the risk of a radiogenic leukaemia is only 1 in 4400 if the excess relative risk (ERR) owing to fetal $x$ ray exposure is $40 \%$. Since the $x$ ray doses to which preterm babies are exposed are about two orders of magnitude less than this, we would expect the ERR to be similarly reduced.

The caveat to this reasoning is that these calculations are based on the assumption that the risk of leukaemia in preterm infants following $x$ ray exposure is the same as that in full term infants. Although there is a paucity of data on this point, there is evidence from clonogenic assays to suggest that cord blood lymphocytes are more radiosensitive than adult lymphocytes, ${ }^{54}$ and it would seem reasonable to expect that this sensitivity might be even greater at a fetal age of 24-30 weeks gestation. Furthermore, the fourfold higher frequency of congenital anomalies in preterm babies compared to those at term, ${ }^{55}$ and the suggestion that about one in 20 antenatal events may lead to malformation and cancer in childhood, ${ }^{56}$ suggests that certain preterm babies might be constitutionally more vulnerable than term babies to the damaging effects of $x$ rays, though this clearly requires further investigation. Finally, the possibility that a small proportion $(<2 \%)$ of preterm infants may be genetically hypersensitive to low dose $x$ rays cannot be excluded on the basis of the results presented in this paper.

We may also have failed to detect fusion gene transcripts owing to the limited amount of preterm infant blood available for analysis. The average amount of RNA that we obtained per $\sim 0.5 \mathrm{ml}$ sample was $6.9 \mu \mathrm{g}$, corresponding to about $7 \times 10^{5}$ cells. Our sample thus represented about $0.5 \%$ of the circulating blood volume of an average preterm infant born at $<30$ weeks, and we used about $1 \mu \mathrm{g}$ RNA to test for each of the three fusion genes, corresponding to $\sim 10^{5} \mathrm{cell}^{52}$ per gene. This means that we analysed slightly less than $0.1 \%$ of the circulating blood in each infant, with a detection threshold of $1-10 \mathrm{pg}$ per fusion gene. To ensure that all of the material in each $1 \mu \mathrm{g}$ RNA sample was tested for each fusion gene, we divided all of the cDNA synthesised in the first round RT-PCR into five replicates for the second round PCR, and tested each of these for fusion gene transcripts.

The cumulative incidence rate for all types of leukaemia in children under 15 years in the UK is 1 in 1760, and for childhood ALL it is 1 in $2183 .{ }^{57}$ Since TEL-AML1 is thought to be present in about $25 \%$ of childhood $\mathrm{ALL}^{31}$ equivalent to about $\mathrm{l}$ in 8000 of the total childhood population, our result showing that it is present in $\sim 2 \%$ of normal full term infants suggests that this fusion gene may be present at a frequency $\sim 160$ times greater than in overt leukaemia. This suggests that TEL-AML1 gene fusion may not give rise to leukaemia unless it involves the appropriate cell lineage and stage of differentiation, and that additional mutations are required for overt leukaemia to develop. It is also possible that immune surveillance mechanisms are able to eliminate TEL-AML1 positive cells ${ }^{58} 59$ in the majority of infants. This would suggest that certain types of childhood leukaemia may arise as a result of defective immune surveillance, and that the immunosuppressive effects of $x$ rays may pose a greater risk than their capacity to cause DNA damage.

In summary, we have been unable to detect three types of leukaemic fusion gene transcript associated with childhood ALL in preterm infants born between 24 and 30 weeks and exposed to multiple diagnostic $x$ rays in the postpartum period. We suggest that currently used $x$ ray doses only constitute a very small risk of causing leukaemia if radiation risk estimates assume that preterm infants are not significantly more radiation sensitive. However, based on the limited numbers of preterm babies that we were able to study we cannot rule out the possibility that the factors that shorten gestation also render the fetus more susceptible to radiation, and that the genetic background of the fetus might have some part to play in this. The presence of a $B C R-A B L$ transcript in one preterm infant was not owing to $x$ ray exposure, but could be explained by a previous blood transfusion. Since the frequency 
of TEL-AML1 transcripts in normal infants greatly exceeds the frequency of childhood ALL with this fusion gene, there may be natural mechanisms that protect against the progression of fusion transcript positive cells to leukaemia.

\section{ACKNOWLEDGEMENTS}

We thank Professor Dudley Goodhead, Director, MRC Radiobiology Unit, Harwell, UK, and an anonymous person for advice and suggestions. We are grateful to the UK Department of Health Imaging Unit for funding P Ravetto (contract RPK 30), and Cancer Research UK for supporting OB Eden. We are grateful to Terri Chant and Judith May, research nurses, for obtaining blood samples from preterm babies on the Neonatal Medical Unit, and the midwives on the Central Delivery Unit at St Mary's Hospital, Manchester for obtaining samples from full term babies.

\section{Authors' affiliations}

P F Ravetto, G M Taylor, University of Manchester, Immunogenetics Laboratory, St Mary's Hospital, Manchester M13 OJH, UK

R Agarwal, M L Chiswick, Neonatal Medical Unit, St Mary's Hospital, Manchester M13 OJH, UK

S W D'Souza, University of Manchester, Academic Unit of Child Health, St Mary's Hospital, Manchester M13 OJH, UK

O B Eden, University of Manchester, Academic Unit of Paediatric

Oncology, Christie Hospital, Manchester, M20 4BX, UK

\section{REFERENCES}

1 Stewart A. Webb J, Giles D, et al. Malignant disease in childhood and diagnostic irradiation in utero. Lancet 1956;ii:447.

2 Stewart A, Kneale GW. Radiation dose effects in relation to obstetric X-rays and childhood cancers. Lancet 1970;i: 1 185-8.

3 MacMahon M. Prenatal X-ray exposure and childhood cancer. J Nat Cancer Inst 1962;28:1173-91.

4 Knox EG Stewart AM, Kneale GW, et al. Prenatal irradiation and childhood cancer. Journal of the Society of Radiological Protection 1987;7:177-89.

5 Bithell JF. Epidemiological studies of children irradiated in utero. In: Baverstock KF, Stather JW, eds. Low dose radiation: biological bases of risk assessment. London: Taylor \& Francis, 1989:77-87.

6 National Radiological Protection Board. Estimates of late irradiation risks to the UK population. Chapter 6: Irradiation in utero. Documents of the NRPB 1993;4:105-25.

7 Doll R, Wakeford R. Risk of childhood cancer from fetal irradiation. $\mathrm{Br}$ J Radiol 1997;70:130-9.

8 Rennie JM. Perinatal management at the lower margin of viability. Arch Dis Child Fetal Neonatal Ed 1996;74:F214-F218.

9 Chervenak FA, McCullough LB. The limits of viability. J Perinat Med 1997;25:418-20.

10 Draper ES, Manktelow B, Field DJ, et al. Prediction of survival for preterm births by weight and gestational age: retrospective population based study. BM 1999;319:1093-7.

11 Fletcher EWL, Baum JD, Draper G. The risk of diagnostic radiation of the newborn. Br J Radiol 1986;59:165-70.

12 Faulkner K, Barry JL, Smalley P. Radiation dose to neonates on a Special Care Baby Unit. Br J Radiol 1989;62:230-3.

13 Arroe $M$. The risk of $X$ ray examinations of the lungs in neonates. Acta Paediatr Scand 1991;80:489-93.

14 Chapple CL, Faulkner K, Hunter EW. Energy imparted to neonates during X-ray examinations in a special care baby unit. Br J Radiol 1994;67:366-70.

15 Sutton PM, Arthur R, Taylor C, et al. lonising radiation from diagnostic $x$ rays in very low birtweight babies. Arch Dis Child Fetal Neonatal Ed 1998;78:F227-F229.

16 McParland BJ, Gorka W, Lee R, et al. Radiology in the neonatal intensive care unit: dose reduction and image quality. Br J Radio 1996;69:927-37.

17 Richardson C, Jasin M. Frequent chromosomal translocations induced by DNA double-strand breaks. Nature 2000;405:697-700.

18 Raimondi SC. Cytogenetics of acute leukemias. In: Pui C-H, ed. Childhood leukemias. Cambridge: Cambridge University Press, 1999: 168-96

19 Rubnitz JE, Look AT. Molecular genetics of acute lymphoblastic leukemia. In: Pui C-H, ed. Childhood leukemias. Cambridge: Cambridge University Press, 1999:97-218.

20 Downing JR. Molecular genetics of acute myeloid leukemia. In: Pui C-H, ed. Childhood leukemias. Cambridge: Cambridge University Press, 1999:219-54.

21 Ford AM, Bennett CA, Price CM, et al. Fetal origins of the TEL-AML1 fusion gene in identical twins with leukemia. Proc Natl Acad Sci U S A 1998;95:4584-8.

22 Wiemels JL, Ford AM, Van Wering ER, et al. Protracted and variable latency of acute lymphoblastic leukaemia after TEL-AML 1 fusion in utero. Blood 1999;94:1057-62.
23 Gale KB, Ford AM, Repp R, et al. Backtracking leukaemia to birth: identification of clonotypic gene fusion sequences in neonatal blood spots. Proc Natl Acad Sci U S A 1997;94:13950-4.

24 Romana SP, Mauchauffé $M$, Le Conia $M$, et al. The $t(12 ; 21)$ of acute lymphoblastic leukaemia results in a tel-AML1 gene fusion. Blood 1995;85:3662-70.

25 Pui CH, Kane JR, Crist WM. Biology and treatment of infant leukaemias. Leukemia 1995:9:762-9.

26 Pui CH, Behm FG, Crist WM. Clinical and biologic relevance of immunologic marker studies in childhood acute lymphoblastic leukemia. Blood 1993;82:343-62

27 Hart D, Jones DG, Wall BF. Coefficients for estimating effective doses from paediatric $X$-ray examinations. National Radiological Protection Board Report, NRPB-R279. London: HMSO, 1996.

28 Uphoff CC, MacLeod RA, Denkmann SA, et al. Occurrence of TEL-AML1 fusion resulting from $(12 ; 21)$ translocation in human early B-lineage leukemia cell lines. Leukemia 1997;11:441-7.

29 Corral J, Forster A, Thompson S, et al. Acute leukemias of different lineages have similar MLL gene fusions encoding related chimeric proteins resulting from chromosomal translocation. Proc Natl Acad Sci U S A 1993;90:8538-42.

30 Pegoraro L, Matera L, Ritz J, et al. Establishment of a Ph 1-positive human cell line (BV173). J Natl Cancer Inst 1983;70:447-53.

31 Cayuela J-M, Baruchel A, Orange C, et al. TEL-AML 1 fusion RNA as a new target to detect minimal residual disease in pediatric B-cell precursor acute lymphoblastic leukemia. Blood 1996;88:302-8.

32 Uken FM, Herman-Hatten K, Crotty M-L, et al. Clinical significance of MLL-AF4 fusion transcript expression in the absence of a cytogenetically detectable $t(4 ; 11)(q 21 ; q 23)$ chromosomal translocation. Blood 1998;92:810-21

33 Saglio G, Pane F, Gottardi E, et al. Consistent amounts of acute leukaemia associated P190 BCR/ABL transcripts are expressed by chronic myelogenous leukaemia patients at diagnosis. Blood 1996;87:1075-80

34 Melo JV. The diversity of $B C R-A B L$ fusion proteins and their relationship to leukaemia phenotype. Blood 1996;88:2375-84.

35 Wall BF, Hart D. Revised radiation doses for typical X-ray examinations. Report of a recent review of doses to patients from medical X-ray examination in the UK by NRPB. Br J Radiol 1997;70:437-9.

36 Huda W, Chamberlain CC, Rosenbaum AE, et al. Radiation doses to infants and adults undergoing head CT examinations. Med Phys 2001;28:393-9.

37 Deininger MWN, Bose S, Gora-Tybor J, et al. Selective induction of leukaemia-associated fusion genes by high-dose ionizing radiation. Cancer Res 1998;58:421-5

38 Spencer A, Granter N. Leukemia patient-derived lymphoblastoid cell lines exhibit increased induction of leukemia-associated transcripts following high-dose irradiation. Exp Hematol 1999;27:1397-401

39 Goodhead DT. Initial events in the cellular effects of ionizing radiations: clustered damage in DNA. Int J Radiat Biol 1994;65:7-17.

40 Kadhim MA, Marsden SJ, Goodhead DT, et al. Long term genomic instabiility in human lymphocytes induced by single-particle irradiation. Radiat Res 2001;155:122-6.

41 Nikiforova MN, Stringer JR, Blough R, et al. Proximity of chromosomal loci that participate in radiation-induced rearrangement in human cells. Science 2000;290: 138-41

42 Kozubek S, Lukášová E, Rýznar L, et al. Distribution of abl and bcr genes in cell nuclei of normal and irradiated lymphocytes. Blood 1997; 89:4537-45

43 Wiemels JL, Cazzaniga G, Daniotti M, et al. Prenatal origin of acute lymphoblastic leukaemia in children. Lancet 1999;354:1499-503.

44 Biernaux C, Loos M, Sels A, et al. Detection of major bcr-abl gene expression at a very low levels in blood cell of some healthy individuals. Blood 1995;86:3118-22.

45 Bose S, Deininger M, Gora-Tybor J, et al. The presence of typical and atypical BCR-ABL fusion genes in leukocytes of normal individuals: biologic significance and implications for the assessment of minimal residual disease. Blood 1998;92:3362-7.

46 Eguchi-Ishimae $M$, Eguchi $M$, Ishii $E$, et al. Breakage and fusion of the TEL (ETV6) gene in immature $B$ lymphocytes induced by apoptogenic signals. Blood 2001;97:737-43.

47 Mori $\mathbf{H}$, Xiao Z, Ford AM, et al. TEL-AML 1 and AML 1-ETO fusion sequences in normal newborn cord bloods. Blood 2000;96:88a.

48 Trka J, Zuna J, Zavacka-Polouckova A, et al. Evidence for the presence of $\mathrm{t}(12 ; 21)$ in cord blood samples of healthy newborns. Blood 2000;96:694a

49 Little JB. Radiation-induced genomic instability. Int J Radiat Biol 1998;74:663-71.

50 Trka J, Zuna J, Hrušák O, et al. No evidence for MLL/AF4 expression in normal cord blood samples. Blood 1999;93:1 106-7.

51 Kim-Rouille M-H, MacGregor A, Wiedemann LM, et al. MLL-AF4 gene fusions in normal newborns. Blood 1999;93:1107-8

52 Schnittger S, Wormann B, Hiddermann W, et al. Partial tandem duplications of the MLL gene are detectable in peripheral blood and bone marrow of nearly all healthy donors. Blood 1998;92:1728-34.

53 Goodhead DT. Track structure considerations in low dose and low dose rate effects of ionizing radiation. Advances in Radiation Biology $1992 ; 16: 7-44$ 
54 Waugh AP, Beare DM, Arlett CF, et al. Comparative human cellular radiosensitivity: IV. The increased sensitivity of human neonatal cord blood lymphocytes to gamma-irradiation compared with lymphocytes from children and adults. Int J Radiat Biol 1991;59:767-76.

55 Linhart Y, Bashiri A, Maymon E, et al. Congenital anomalies are an independent risk factor for neonatal morbidity and perinatal mortality in preterm birth. Eur J Obstet Gynaecol Reprod Biol 2000;90:43-9.

56 Mann JR, Dodd HE, Draper GJ, et al. Congenital abnormalities in children with cancer and their relatives: results from a case-control study (IRESCC). Br J Cancer 1993;68:357-63.
57 Stiller CA Allen MB, Eatock EM. Childhood cancer in Britain: the national registry of childhood tumours and incidence rates 1978-1987. Eur J Cancer 1995;31A:2028-34.

58 Yotdna P, Garcia F, Peuchmaur M, et al. Cytotoxic T cell response against the chimeric ETV6-AML1 protein in childhood acute lymphoblastic leukemia. J Clin Invest 1998;102:455-62.

59 Yun C, Senju S, Fujita H, et al. Augmentation of immune reponses by altered peptide ligands of the antigenic peptide in a human CD4+ T-cell clone reacting to TEL/AML1 fusion protein. Tissue Antigens 1999;54:153-61

\section{Clinical Evidence-Call for contributors}

Clinical Evidence is a regularly updated evidence based journal available worldwide both as a paper version and on the internet. Clinical Evidence needs to recruit a number of new contributors. Contributors are health care professionals or epidemiologists with experience in evidence based medicine and the ability to write in a concise and structured way.

Currently, we are interested in finding contributors with an interest in the following clinical areas:

Altitude sickness; Autism; Basal cell carcinoma; Breast feeding; Carbon monoxide poisoning; Cervical cancer; Cystic fibrosis; Ectopic pregnancy; Grief/bereavement; Halitosis; Hodgkins disease; Infectious mononucleosis (glandular fever); Kidney stones; Malignant melanoma (metastatic); Mesothelioma; Myeloma; Ovarian cyst; Pancreatitis (acute); Pancreatitis (chronic); Polymyalgia rheumatica; Post-partum haemorrhage; Pulmonary embolism; Recurrent miscarriage; Repetitive strain injury; Scoliosis; Seasonal affective disorder; Squint; Systemic lupus erythematosus; Testicular cancer; Varicocele; Viral meningitis; Vitiligo

However, we are always looking for others, so do not let this list discourage you.

Being a contributor involves:

- Appraising the results of literature searches (performed by our Information Specialists) to identify high quality evidence for inclusion in the journal.

- Writing to a highly structured template (about 2000-3000 words), using evidence from selected studies, within 6-8 weeks of receiving the literature search results.

- Working with Clinical Evidence Editors to ensure that the text meets rigorous epidemiological and style standards.

- Updating the text every eight months to incorporate new evidence.

- Expanding the topic to include new questions once every 12-18 months.

If you would like to become a contributor for Clinical Evidence or require more information about what this involves please send your contact details and a copy of your CV, clearly stating the clinical area you are interested in, to Claire Folkes (cfolkes@bmigroup.com).

\section{Call for peer reviewers}

Clinical Evidence also needs to recruit a number of new peer reviewers specifically with an interest in the clinical areas stated above, and also others related to general practice. Peer reviewers are health care professionals or epidemiologists with experience in evidence based medicine. As a peer reviewer you would be asked for your views on the clinical relevance, validity, and accessibility of specific topics within the journal, and their usefulness to the intended audience (international generalists and health care professionals, possibly with limited statistical knowledge). Topics are usually 2000-3000 words in length and we would ask you to review between 2-5 topics per year. The peer review process takes place throughout the year, and our turnaround time for each review is ideally 10-14 days.

If you are interested in becoming a peer reviewer for Clinical Evidence, please complete the peer review questionnaire at www.clinicalevidence.com or contact Claire Folkes (cfolkes@bmigroup.com). 